\title{
A Conceptual Framework on the Relationship between Nation Brand Perception and Donation Behaviour
}

\author{
Jessica Helmi \\ Deakin University, Melbourne, Australia \\ E-mail: jessica.helmi@deakin.edu.au \\ Riza Casidy Mulyanegara \\ Swinburne University of Technology, Melbourne, Australia \\ E-mail: rmulyanegara@swin.edu.au
}

Received: June 2, 2011

doi:10.5539/ijbm.v6n12p36
Accepted: July 18, $2011 \quad$ Published: December 1, 2011

URL: http://dx.doi.org/10.5539/ijbm.v6n12p36

\begin{abstract}
Over the past two decades, the topic of nation brands has attracted the interest of academics, researchers, and policy markers alike. This study developed a conceptual framework of donation behaviour with nation brand perceptions as a mediating variable between donation motives and donation behaviour. The framework proposes that people's perception of a nation's brand will have significant implications on the willingness and extent of contribution to a charitable cause associated with the nation. The brand image of charitable organisations is proposed to moderate the relationship between nation brand perception and donation behaviour. The study also proposed that integrated marketing communications will significantly affect the perception of nation brands and the brand image of the charitable organisations. The paper concludes by discussing the practical and theoretical implications of the study.
\end{abstract}

Keywords: Donation behaviour, Nation brands, Non-profit marketing

\section{Introduction}

In an increasingly competitive environment, not only companies but also countries are engaged in various efforts to establish distinguishing identities which set them apart from other nations. Over the past decade, the topic of 'nation branding' has attracted the interests of academicians and policy makers alike, driven by the belief that a strong nation brand can contribute to sustainable development (Jaffe \& Nebenzahl, 2001), restore international credibility, enhance global political influence, and encourage stronger partnership with other nations (Yan, 2003).

The concepts of nation branding have been discussed in the marketing literature since the early 1990's. Kotler, et.al (1993) were among the first scholars who discussed the topic of nation branding to attract investments and tourisms to cities, nations, and places. An overview of the literature suggests that there are four main marketing domains which underpin the theoretical foundations of 'nation branding': (i) "country of origin" (Parameswaran \& Pisharodi, 1992; Roth \& Romeo, 1992; Shimp, Saeed, \& Madden, 1993), (ii) country-product image (Martin \& Eroglu, 1993; Parameswaran \& Yaprak, 1987), (iii) destination branding (Hankinson, 2007; Pritchard \& Morgan, 1998), and (iv) country identity (Anholt, 2007; Keillor \& Hult, 1999; Keillor, Hult, Erffmeyer, \& Babakus, 1996). Although most discussions of nation branding appeared in the marketing literature, in recent years it has become evident that the topic is much broader than marketing as it involves various disciplines such as international relations, political science, and public diplomacy (Anholt, 2003).

Despite an increasing amount of research on the topic of 'nation branding' over the past decade, few studies have discussed the role of nation brands in the non-profit marketing literature. Indeed, most studies in the past focused on the conceptual definition of nation brand (Fan, 2006), the objective measurement that assesses the strength of a nation brand (Fetscherin, 2010), and the viable means to help nations assess what they are communicating to the international audiences (Opoku \& Hinson, 2006). To the best of our knowledge, there have not been any empirical studies devoted to examine the role of nation brands in donation-related behaviour.

This study aims to provide a conceptual framework to examine the effects of donors' perception of nation brands 
on donation behaviour. More specifically, it attempts to examine whether, how much, and why the perception about particular nation brands influences the willingness and extent of a donor's contribution. An important feature of this study is the incorporation of factors that are believed to have significant impact on donors' willingness to contribute to disaster-relief, child sponsorship, and other charity-related projects.

\section{Nation Brands}

Dinnie (2008) referred to nation branding as an 'exciting', 'complex', and 'controversial' research topic. The topic is 'exciting' as it represents a domain in which there are few existing theories but a substantial amount of real world activity; 'complex' because it encompasses interdisciplinary approaches beyond the realm of marketing literature; and 'controversial' as it is a politically-driven activity that frequently generates conflicting beliefs and perspectives. Despite an array of studies in this area, it has been argued that the topic is still in its infancy and only in the past decade that an increasing number of academics and practitioners have focused on nation branding as a research topic (Fetscherin, 2010). Until recently, the topic was still considered "an emerging area of interest...driven largely by practitioners and there is an urgent need for conceptual and theoretical development of the subject" (Fan, 2010, p.98). An overview of the literature reveals extant research gaps in the definition of nation brand (Fan, 2006), the objective measurement that assesses the strength of a nation brand (Fetscherin, 2010), the viable means to help nations assess what they are communicating to the international audiences (Opoku \& Hinson, 2006), and the consequences of nation brands on consumer behaviour (Dinnie, 2008).

The literature made a distinction between the concept of 'nation brands' and 'nation branding'. Nation brands are defined as "the total sum of all perceptions of a nation in the minds of international stakeholders, which may contain some of the following elements: people, place, culture / language, history, food, fashion, famous faces (celebrities), global brands and so on" (Fan, 2010, p.98). Other definitions which have been documented in the literature include: a complex brand identity and image which encompasses national reality, its perceptions and evaluations by many internal and external stakeholders (Walsh \& Wiedmann, 2008); a combination of name, related terms, marks, symbols, design which all serve to differentiate them from other countries (Kotler \& Gertner, 2002); an umbrella under which further sub-brands can be expanded (Szondi, 2010).

Nation branding, on the other hand, is defined as "the strategic self-presentation of a country with the aim of creating reputational capital through economic, political and social interest promotion at home and abroad" (Szondi, 2008, p.5). Fan (2006, p.6) asserted that "nation branding concerns applying branding and marketing communications techniques to promote a nation's image" whilst Loo and Davies (Loo \& Davies, 2006) takes a similar stance by suggesting that nation branding serves to manage all individual images into a coherent, holistic image that addresses the needs of most of the nation's various stakeholders. In the literature, nation branding is mostly conceptualised as a way to achieve nation brand equity and competitiveness. The practice of nation branding emerged as nations turn to brand management experts to develop their image in order to 'compete' effectively on the world stage against other nations (Dinnie, 2008). Indeed, nation-branding process is a highly politicized activity given the fact that government is seen as the representation of the people in a nation.

Fan (2006) classified the interpretation of nation branding into four levels: (i) export branding, (ii) destination/place branding, (iii) public diplomacy/political branding, and (iv) national identity/cultural branding. At the first level, the simplest approach to develop a nation brand is through visual symbol or slogan. Therefore, the nation can be easily branded and communicated in this level. At the second level, a nation brand is viewed as an umbrella brand that encompasses many sub-sectors such as tourism or export destinations. At the third level, a nation brand concerns the country's image, reputation, and positioning which is similar to the role of corporate branding (Roth \& Diamantopoulos 2009). Finally, at the fourth level, nation branding can be used as an important tool in developing and maintaining a nation's political power, as successful nation branding campaign will help create a more favourable image among the international audience and thus enhance the country's 'soft power' (Fan 2008).

The impact of nation brand image on industrial and household consumer decision making processes has been well documented in the literature (Jaffe \& Nebenzahl, 2001; Marguerite \& Jason, 2008; Roth \& Romeo, 1992). Han and Tepstra (1988) argued that the effects of nation brands image on consumer's purchase decision is stronger than the product's brand image. This is consistent with Roth and Romeo's (1992) findings which suggested that consumers' willingness to buy products could be enhanced by promoting the image of the nations. Positive nation brand image can be used to gain competitive advantage in international marketing (Parameswaran \& Pisharodi, 1994) and to influence consumers' perceptions of product quality in various ways (Peterson \& Jolibert, 1995). Despite the increasing number of studies examining the relationship between nation brands and consumer behaviour, there are extant gaps in the relationship between nation branding and donation behaviour, as most studies in the past were conducted in commercial context. 


\section{Donation Behaviour}

The non-profit sector is an important part of the Australian economy, contributing \$38 billion (3.4\%) to the GDP, which is equivalent to that of the government administration and defense industry (ABS, 2008). Philanthropy Australia estimated that the total donation of money, goods, and services to non-profit organisations by individuals and businesses in the year 2005 amount to a total of \$11 billion (Philantrophy Australia Inc"Fast Facts \& Statistics on Philanthropy," 2005). The Australian Taxation Office reported \$2.3 billion worth of individual donations claimed in the 2007 - 2008 income year, which is a notable $24.5 \%$ increase from the previous year (Philantrophy Australia Inc"Fast Facts \& Statistics on Philanthropy," 2005).

There is an abundant amount of research across various disciplines on what motivates donors to give. Research on this topic stems from economics (Kohm \& Ythier, 2006; Steinberg, 2006), psychology (Batson, 1990; Carlson, Charlin, \& Miller, 1988; Penner, Dovidio, Piliavin, \& Schroeder, 2005), sociology (Havens, O’Herlihy, \& Schervish, 2006), and non-profit marketing (Bendapudi, Surendra, \& Venkat, 1996; Briggs, Landry, \& Wood, 2007; Brown, 2004). More recently, philanthropic studies researchers have presented their own insights to explain the motivations for donation behaviour (Bekkers \& Wiepking, 2007; Sargeant \& Woodliffe, 2007).

Bekkers and Wiepking $(2007$, p.2) define charitable giving as the "donation of money to an organisation that benefits others beyond one's own family". A review of literature by Bekkers and Wiepking (2007) identified eight key motives that drive donation behaviour: (i) awareness of needs, (ii) solicitation, (iii) costs and benefits, (iv) altruism, (v) reputation, (vi) psychological benefits, (vii) values, and (viii) efficacy.

Wagner and Wheeler (1969) argued that it is the subjective perceptions of need (rather than objective) that drive people to donate. Other studies also suggest that this awareness of need will be enhanced if they know the beneficiaries of the charitable organisation (Radley \& Kennedy, 1995). Mass media plays an important role in increasing prospective donors' awareness of needs. Frequency of television advertisement related to a charitable cause is found to be positively associated with the amount of donation received by charitable organisations (Bennett \& Kottasz, 2000). This suggests that the subjective awareness of need as a result of a marketing activity is the driving factor that enhances contributions to the advertised cause (Polonsky, Shelley, \& Voola, 2002).

\section{Conceptual Framework}

The notion that subjective perception of needs drive people to donate is the fundamental premise for our conceptual framework (Wagner \& Wheeler, 1969). The first focus of this study is on the mediating role of nation brand perceptions on the relationship between donation motives (as identified by Bekkers and Wiepking (2007)) and donation behaviour. According to Baron and Kenny (1986), a variable performs a mediating role if it accounts for the relationship between the antecedents and the results. Though people may have various motives when it comes to donating to a charitable cause, their perception of the nations' brand may affect their willingness and extent of donations. Poor and less developed nations may appeal more strongly to donors, particularly in unexpected circumstances such as natural disasters. Prospective donors may be inclined to give more to less developed nations due to their perception that such nations may not be able to afford the costs associated with recovering from the disasters. On the other hand, more developed nations may be less appealing to prospective donors even in unexpected circumstances such as natural disasters. During the Japan's 2011 Tsunami relief, it was evident that most donations came from developed countries mainly United Kingdom, United States, and South Korea. Although other developing nations also contribute to the relief fund, most of the private donations came from donors from developed nations (Anonymous, 2011). Nation brand perceptions not only affect the extent of giving. Rather, it can be argued that people's perception of nation brands eventually account for the relationship between donation motives and donation behaviour, leading us to the first proposition.

\section{Proposition 1}

\section{Perception of nation brands mediates the relationship between donation motives and donation behaviour}

The second focus of this study is on the link between brand image of charitable organisations and donation behaviour. The literature has provided strong support on the links between strong brands and non-profit organisations' performance. Previous studies suggest that strong brands can: (i) enhance an organisation's ability to communicate its values to stakeholders (Tapp, 1996); (ii) change public opinion (Lindsay \& Murphy, 1996); (iii) build loyalty (Ritchie, Swami, \& Weinberg, 1999); (iv) achieve short-term and long-term objectives (Hankinson, 2002; Simoes \& Dibb, 2001); and (v) attract a greater proportion of voluntary income (Hankinson, 2001). Bennett and Gabriel (2003) asserted that the reputation of charitable organisations is one of the driving factors behind donation behaviour. However, despite this conceptual support, very little empirical evidence exists to substantiate the relationship between brand image and donation behaviour in measurable terms.

This study proposes that the brand image of charitable organisations moderates the relationship between nation 
brand perception and donation behaviour. In our view, the strength of relationship between donors' nation brand perception and the actual donation behaviour will be determined by the brand image of charitable organisations. A reputable charity organisation that has run projects closely associated with the nations in need for a long period is more likely to attract donors' contribution as compared to newly established organisations. However, given the lack of empirical evidence on the relationship between the two constructs, it is too early to specify an exact relationship between them. Some authors have asserted that there are many opportunities for non-profit organisations to use commercial branding practices in the development of non-profit brands (Roberts-Wray, 1994; Tapp, 1996), whereas others have argued that non-profit organisations should not be too impetuous in replicating commercial approaches to branding because so-called 'over-commercialisation' might have adverse effects on the distinctive nature of non-profit organisations (Sternberg, 1998)

\section{Proposition 2}

The brand image of charitable organisations moderates the relationship between nation brand perception and donation behaviour.

The final focus of this study is on the role of integrated marketing communications (IMC) in affecting both people's perception of the nation brands and the brand image of charitable organisations. A review of the literature (Bridson \& Evans, 2004; Ewing \& Napoli, 2005; Simoes \& Dibb, 2001) suggest the notion that 'brand orientation' should be integrated in all organisational function to build a strong connection with organisations' stakeholders. On this basis, Reid, Luxton, \& Mavondo (2005, p.16) argued that there is a 'close relationship and interdependence of brand orientation and IMC'. The authors further suggest that customer values are created outside the physical product through elements such as customer interaction, responsiveness to feedback, and customer needs and expectations, all of which are communicated using IMC elements.

The role of marketing communications in affecting nation brand perception (Anholt, 2007; Dinnie, 2008; Hankinson, 2007) and the brand image of charitable organisations (Bennett, 2003; Stride \& Lee, 2007; Tapp, 1996) have been widely acknowledged in the literature. Mass media plays an important role in increasing prospective donors' awareness of needs. Frequency of television advertisement related to a charitable cause is found to be positively associated with the amount of donation received by charitable organisations (Bennett \& Kottasz, 2000). This suggests that the subjective awareness of need as a result of a marketing activity is the driving factor that enhances contributions to the advertised cause (Polonsky, et al., 2002). This study aims to replicate previous studies in this area through an examination of the role of IMC in affecting nation brand perception and the brand image of charitable organisations within the context of disaster-relief appeals.

\section{Proposition 3}

Integrated marketing communications is significantly related to nation brand perceptions and the brand image of the charitable organisations

\section{Discussions}

An overview of the literature in the preceding sections has highlighted the theoretical underpinnings on the issues of 'nation branding' and 'donation behaviour'. Despite the abundance of research in the respective areas, there are notable gaps in the literature on the examination of the role of nation brands in donation behaviour context. Particularly, the literature offers little explanation as to whether people's perception of a nation's brand might affect their willingness to donate to charitable causes related to the nation. This study attempted to contribute to the literature through providing a conceptual framework to observe the role of nation brands, IMC, and brand image in affecting donation behaviour.

The conceptual framework in figure 1 is designed to illustrate the relationship between nation brand perception, donation behaviour, integrated marketing communications, and brand image of the charitable organisations. Throughout the paper, we have attempted to show the complementaries between the constructs in the conceptual framework. The arguments presented in this study have implications for managers of charitable organisations. Over the past two decades, the non-profit sector has faced a challenging environment as a result of increasing demand for its services, reductions in financial support from government, and a growing number of participants, which has increased competitive rivalry within the sector (Balabanis, Stables, \& Phillips, 1997). An effective implementation of nation brand appeals can encourage donation behaviour, as certain countries might possess an image that is highly appealing to particular donors. The IMC of the charitable organisations should also be directed to enhance the links between the organisation's image and the nation brand of the charity project. As per the conceptual framework, an effective IMC will lead to positive brand image which may enhance the strength of relationship between nation brand perception and donation behaviour.

The topic of the present study is important for several reasons. First, the study promises to make a significant contribution to the non-profit marketing literature. The role of 'nation brands' in the context of donation 
behaviour remains significantly under-researched, especially in terms of empirical studies. Secondly, the present study developed a comprehensive framework which links 'nation brands' and 'donation behaviour'. For the most part, the two have progressed independently of each other in the literature. The present study makes a significant contribution by integrating theories from these two research domains to explain the phenomenon of nation brands from the perspective of donors - that is, the study contends that the perceptions of donors regarding a nation's brand influence their willingness to donate and the extent of their contribution to causes related to the particular nation.

This study is constrained by limitations which can be addressed in future studies. First, there is a lack of empirical evidence on the links between variables discussed in the conceptual framework. Most of the studies in the past were conceptual in nature and despite the abundance of recent research on the topic of 'nation brands', little empirical evidence has been established to substantiate the relationship between nation brand perception and donation behaviour. Secondly, the most difficult part of the framework relates to the development of scales that sufficiently reflect the essence of the IMC process in charitable organisations which can be linked to organisations' brand image and donation behaviour. Most constructs in the existing literature measure IMC through extent of promotional efforts but few studies have examined the IMC items which are relevant to enhancing nation brand appeals.

We contend that the conceptual framework presented in this paper can be testable in future studies. The measure of donation motives, nation brand perception, brand image, and donation behaviour has been well established in the literature. The data analysis implied by the framework (which involves Structural Equation Modeling) is well established to assess direct, indirect, and total effects of donation motives and IMC (as independent variables) through nation brand perception, and the direct effects of nation brand perception on donation behaviour. The value of empirically examine this framework will be observed through a deeper understanding of the relationship between nation brands, donation behaviour, and non-profit organisations' performance.

\section{References}

ABS. (2008). Year book Australia 2008. Canberra: Australian Bureau of Statistics.

Anholt, S. (2003). Chapter 14: Branding places and nations (pp. 213-226). EIU: Economist Intelligence Unit.

Anholt, S. (2007). Competitive Identity: The New Brand Management for Nations, Cities and Regions. Basingstoke: Palgrave Macmillan.

Anonymous. (2011). FACTBOX-Aid and rescue offers for Japan quake. [Online] Available: http://www.trust.org/alertnet/news/factbox-aid-and-rescue-offers-for-japan-quake/ (1 June 2011, 2011)

Balabanis, G., Stables, R. E., \& Phillips, H. C. (1997). Market orientation in the top 200 British charity organizations and its impact on their performance. European Journal of Marketing, 31, 7/8, 583-603. http://dx.doi.org/10.1108/03090569710176592

Baron, R. M., \& Kenny, D. A. (1986). The Moderator-Mediator Variable Distinction in Social Psychological Research: Conceptual, Strategic, and Statistical Considerations. Journal of Personality and Social Psychology, 51, 6, 1173-1182. http://dx.doi.org/10.1037/0022-3514.51.6.1173

Batson, D. C. (1990). How Social an Animal? The Human Capacity for Caring. American Pscyhologist, 45, 3, 336-346. http://dx.doi.org/10.1037/0003-066X.45.3.336

Bekkers, R., \& Wiepking, P. (2007). Generosity and Philanthropy, A Literature Review (Working Paper). University of Amsterdam.

Bendapudi, N., Surendra, N. S., \& Venkat, B. (1996). Enhancing Helping Behavior: An Integrative Framework for Promotion Planning. Journal of Marketing, 60, 3, 33.

Bennett, R. (2003). Factors underlying the inclination to donate to particular types of charity. International Journal of Nonprofit \& Voluntary Sector Marketing, 8, 1, 12.

Bennett, R., \& Gabriel, H. (2003). Image and reputational characteristics of UK charitable organizations: An empirical study. Corporate reputation review, 6, 276-289. http://dx.doi.org/10.1057/palgrave.crr.1540206

Bennett, R., \& Kottasz, R. (2000). Emergency fund-raising for disaster relief. Disaster Prevention and Management, 9, 5, 352-360. http://dx.doi.org/10.1108/09653560010361393

Bridson, K., \& Evans, J. (2004). The secret to a fashion advantage is brand orientation. International Journal of Retail \& Distribution Management, 32, 8/9, 403.

Briggs, E., Landry, T., \& Wood, C. (2007). Beyond Just Being There: An Examination of the Impact of Attitudes, Materialism, and Self-Esteem on the Quality of Helping Behavior in Youth Volunteers. Journal of Nonprofit \& Public Sector Marketing, 18, 2, 27-45. http://dx.doi.org/10.1300/J054v18n02_02 
Brown, D. W. (2004). What research tells us about planned giving. International Journal of Nonprofit and Voluntary Sector Marketing, 9, 86-95. http://dx.doi.org/10.1002/nvsm.235

Carlson, M., Charlin, V., \& Miller, N. (1988). Positive Mood and Helping Behaviour: A Test of Six Hypotheses. Journal of Personality and Social Psychology, 55, 2, 211-229. http://dx.doi.org/10.1037/0022-3514.55.2.211

Dinnie, K. (2008). Nation Branding: concepts, issues, practice. Amsterdam: Elsevier.

Ewing, M. T., \& Napoli, J. (2005). Developing and validating a multidimensional nonprofit brand orientation scale. Journal of Business Research, 58, 6, 841-853. http://dx.doi.org/10.1016/j.jbusres.2003.09.012

Fan , Y. (2008). Soft power: The power of attraction or confusion. Place Branding and Public Diplomacy, 4, 2 , 147-158. http://dx.doi.org/10.1057/pb.2008.4

Fan, Y. (2006). Branding the nation: what is being branded? Journal of Vacation Marketing, 12, 1, 5-14. http://dx.doi.org/10.1177/1356766706056633

Fan, Y. (2010). Branding the nation: Towards a better understanding. Place Branding \& Public Diplomacy, 6, 2, 97-103. http://dx.doi.org/10.1057/pb.2010.16

Fast Facts \& Statistics on Philanthropy. (2005). [Online] Available: http://www.philanthropy.org.au/research/fast.htm (15 April, 2011)

Fetscherin, M. (2010). The determinants and measurement of a country brand: the country brand strength index. International Marketing Review, 27, 4, 466-479. http://dx.doi.org/10.1108/02651331011058617

Han, C. M., \& Terpstra, V. (1988). Country-of-origin effects for uni-national and binational products. Journal of International Business Studies, 19, 2, 235-255. http://dx.doi.org/10.1057/palgrave.jibs.8490379

Hankinson, G. (2007). The management of destination brands: Five guiding principles based on recent developments in corporate branding theory. Journal of Brand Management, 14, 3, 240-254. http://dx.doi.org/10.1057/palgrave.bm.2550065

Hankinson, P. (2001). Brand orientation in the Top 500 fundraising charities in the UK. Journal of Product \& Brand Management, 10, 6, 346-360. http://dx.doi.org/10.1108/10610420110406040

Hankinson, P. (2002). The impact of brand orientation on managerial practice: A quantitative study of the UK's top 500 fundraising managers. International Journal of Nonprofit \& Voluntary Sector Marketing, 7, 1, 30-44. http://dx.doi.org/10.1002/nvsm.165

Havens, J. J., O’Herlihy, M. A., \& Schervish, P. G. (2006). Charitable Giving: How Much, by Whom, to What, and How? The Nonprofit Sector: A Research Handbook. 2nd ed (pp. 542-567). New Haven: Yale University Press.

Jaffe, E., \& Nebenzahl, D. (2001). National Image and Competitive Advantage: The Theory and Practice of Country-of-Origin Effect. Copenhagen: Copenhagen Business School Press.

Keillor, B. D., \& Hult, G. T. M. (1999). A five country study of national identity: implications for international marketing research and practice. International Marketing Review, 16, 1, 65-84. http://dx.doi.org/10.1108/02651339910257656

Keillor, B. D., Hult, G. T. M., Erffmeyer, R. C., \& Babakus, E. (1996). NATID: the development and application of a national identity measure for use in international marketing. Journal of International Marketing, 4, 2, 57-73.

Kohm, S.-C., \& Ythier, J. M. (2006). Handbook of Giving, Reciprocity and Altruism. Amsterdam: North Holland.

Kotler, P., \& Gertner, D. (2002). Country as brand, product, and beyond: a place marketing and brand management perspective. Journal of Brand Management, 9, 4/5, 249-261. http://dx.doi.org/10.1057/palgrave.bm.2540076

Kotler, P., Haider, D. H., \& Rein, I. (1993). Marketing Places: Attracting Investment, Industry, and Tourism to Cities, States, and Nations New York: The Free Press.

Lindsay, G., \& Murphy, A. (1996). NSPCC: marketing the 'solution' not the 'problem'. Journal of Marketing Management, 12, 3, 707-718. http://dx.doi.org/10.1080/0267257X.1996.9964448

Loo, T., \& Davies, G. (2006). Branding China: the ultimate challenge in reputation management? Corporate Reputation Review, 6, 3, 198-210. http://dx.doi.org/10.1057/palgrave.crr.1550025

Marguerite, M., \& Jason, M. C. (2008). Intergenerational perceptions of market cues among US apparel consumers. Journal of Fashion Marketing \& Management, 12, 3, 323-337. http://dx.doi.org/10.1108/13612020810889281 
Martin, I. M., \& Eroglu, S. (1993). Measuring a multi-dimensional construct: country image. Journal of Business Research, 28, 3, 191-210. http://dx.doi.org/10.1016/0148-2963(93)90047-S

Opoku, R., \& Hinson, R. (2006). Online brand personalities: An exploratory analysis of selected African countries. Place Branding, 2, 2, 118-129. http://dx.doi.org/10.1057/palgrave.pb.5990050

Parameswaran, R., \& Pisharodi, R. (1994). Facets of country of origin image: an empirical assessment. Journal of Advertising, 23, 1, 43-56.

Parameswaran, R., \& Pisharodi, R. M. (1992). Confirmatory factor analysis of a country-of-origin scale: initial results. Advances in Consumer Research, 19, 706-714.

Parameswaran, R., \& Yaprak, A. (1987). A cross-national comparison of consumer research measures. Journal of International Business Studies, 18, 1, 35-49. http://dx.doi.org/10.1057/palgrave.jibs.8490398

Penner, L. A., Dovidio, J. F., Piliavin, J. A., \& Schroeder, D. A. (2005). Prosocial Behavior: Multilevel $\begin{array}{lllll}\text { Perspectives. Annual } & \text { Review } & \text { 365-392. }\end{array}$ http://dx.doi.org/10.1146/annurev.psych.56.091103.070141

Peterson, R. A., \& Jolibert, A. J. (1995). A meta-analysis of country-of-origin effects. Journal of International Business Studies, 26, 4, 883-900. http://dx.doi.org/10.1057/palgrave.jibs.8490824

Polonsky, M. J., Shelley, L., \& Voola, R. (2002). An Examination of Helping Behavior-Some Evidence from Australia. Journal of Nonprofit \& Public Sector Marketing, $10, \quad 2, \quad 67 \quad-\quad 82$. http://dx.doi.org/10.1300/J054v10n02_04

Pritchard, A., \& Morgan, N. (1998). Mood marketing - the new destination branding strategy: a case study of 'Wales', the brand. Journal of Vacation Marketing, 4, 3, 215-229.

Radley, A., \& Kennedy, M. (1995). Charitable Giving by Individuals: A Study of Attitudes and Practice. Human Relations, 48, 6, 685-709. http://dx.doi.org/10.1177/001872679504800605

Reid, M., Luxton, S., \& Mavondo, F. (2005). The Relationship between Integrated Marketing Communication, Market Orientation, and Brand Orientation. Journal of Advertising, 34, 4, 11-23.

Ritchie, R. J. B., Swami, S., \& Weinberg, C. B. (1999). A brand new world for nonprofits. International Journal of Nonprofit and Voluntary Sector Marketing, 4, 1, 26-42. http://dx.doi.org/10.1002/nvsm.54

Roberts-Wray, B. (1994). Branding, Product development, and positioning the charity. Journal of Brand Management, 1, 6, 363-367.

Roth , K. P., \& Diamantopoulos , A. (2009). Advancing the country image construct Journal of Business Research, 62, 7, 726-740. http://dx.doi.org/10.1016/j.jbusres.2008.05.014

Roth, M. S., \& Romeo, J. B. (1992). Matching product category and country image perceptions: a framework for managing country-of-origin effects. Journal of International Business Studies, 23, 3, 477-497. http://dx.doi.org/10.1057/palgrave.jibs.8490276

Sargeant, A., \& Woodliffe, L. (2007). Gift Giving: An Interdisciplinary Review. International Journal of Nonprofit Marketing and Voluntary Sector Marketing, 12, 4, 275-308.

Shimp, T. A., Saeed, S., \& Madden, T. J. (1993). Countries and their products: a cognitive structure perspective. Journal of the Academy of Marketing Science, 21, 4, 323-330. http://dx.doi.org/10.1007/BF02894524

Simoes, C., \& Dibb, S. (2001). Rethinking the brand concept: New brand orientation. Corporate Communications, 6, 4, 217-224. http://dx.doi.org/10.1108/13563280110409854

Steinberg, R. (2006). Economic Theories of Nonprofit Organizations. In W. Powell \& R. Steinberg (Eds.), The Nonprofit Sector, A Research Handbook (pp. 117-139). New Heaven: CT: Yale University Press.

Sternberg. (1998). The third way: The repositioning of the voluntary sector. Journal of Nonprofit and Voluntary Sector Marketing, 3, 3, 209-217.

Stride, H., \& Lee, S. (2007). No Logo? No Way. Branding in the Non-Profit Sector. Journal of Marketing Management, 23, 1/2, 107-122. http://dx.doi.org/10.1362/026725707X178585

Szondi, G. (2008). Public diplomacy and nation branding: conceptual similarities and differences Discussion papers in Diplomacy. The Hague: The Netherlands Institute of International Relations "Clingendael".

Szondi, G. (2010). From image management to relationship building: A public relations approach to nation branding. Place Branding \& Public Diplomacy, 6, 4, 333-343. http://dx.doi.org/10.1057/pb.2010.32

Tapp, A. (1996). Charity Brands, a Qualitative Study of Current Practice. Journal of Nonprofit and Voluntary Sector Marketing, 1, 4, 327-336. http://dx.doi.org/10.1002/nvsm.6090010406 
Wagner, C., \& Wheeler, L. (1969). Model, need, and cost effects in helping behaviour. Journal of Personality and Social Psychology, 12, 2, 111-116. http://dx.doi.org/10.1037/h0027569

Walsh, G., \& Wiedmann, K. P. (2008). Branding Germany-managing internal and external country reputation. In K. Dinnie (Ed.), Nation Branding: concepts, issues, practice (pp. 154-158). Butterworth-Heinemann: Oxford.

Yan, J. (2003). Branding and the international community. Journal of Brand Management, 10, 6, 447.

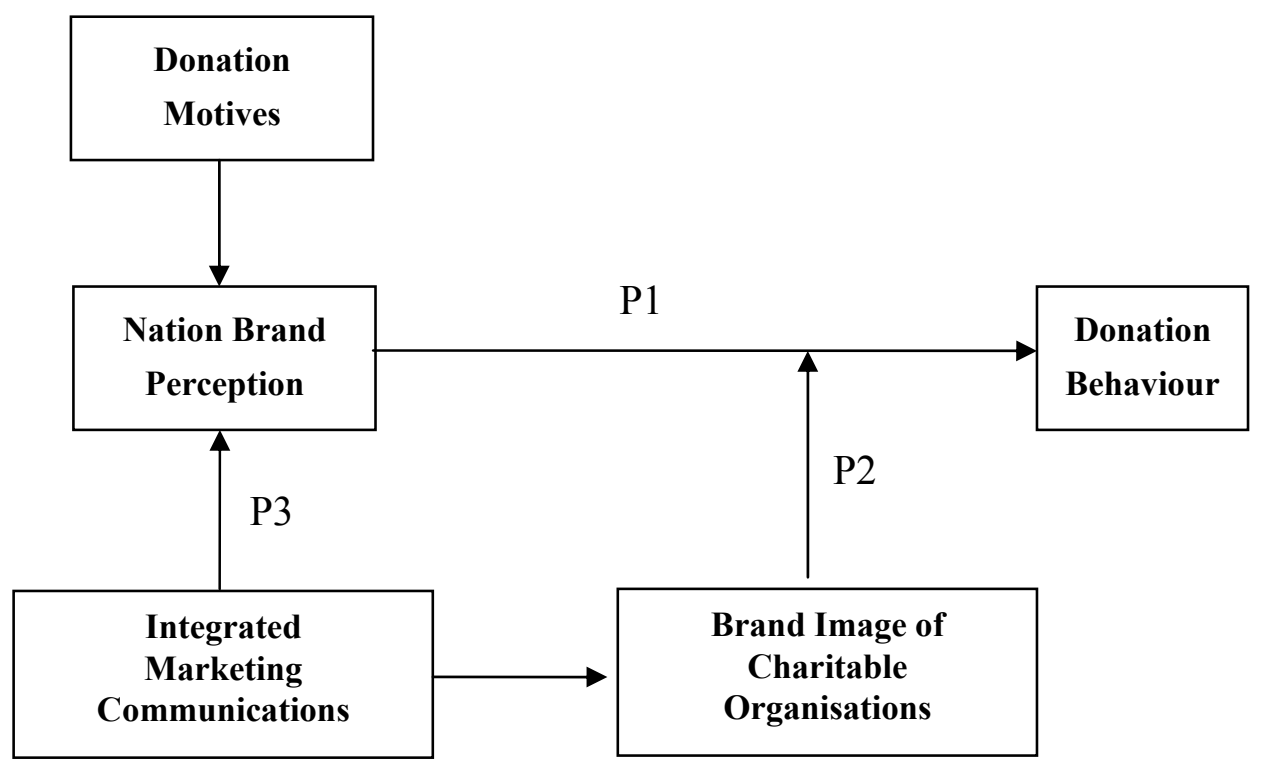

Figure 1. Conceptual Framework 